\title{
Spot protein/creatinine ratio as a marker for fetomaternal outcome in hypertensive disorder of pregnancy
}

\author{
Ashima Taneja, Gagandeep Kaur*, Manpreet Kaur, Muskan Chaudhary, Kulvir Kaur
}

Department of Obstetrics and Gynecology, Dayanand Medical College and Hospital, Ludhiana, Punjab, India

Received: 13 August 2019

Revised: 08 November 2019

Accepted: 13 November 2019

\author{
*Correspondence: \\ Dr. Gagandeep Kaur, \\ E-mail: prinni_kakkar_123@yahoo.com
}

Copyright: (c) the author(s), publisher and licensee Medip Academy. This is an open-access article distributed under the terms of the Creative Commons Attribution Non-Commercial License, which permits unrestricted non-commercial use, distribution, and reproduction in any medium, provided the original work is properly cited.

\begin{abstract}
Background: Gestational hypertension is defined as systolic BP level of $>140 \mathrm{mmHg}$ or a diastolic $\mathrm{BP}$ of $>90$ $\mathrm{mmHg}$ that occur after 20 weeks of gestation. Pre-eclampsia is the hypertensive disorder of pregnancy, associated with adverse fetomaternal complications. It is assosciated with proteinuria. 24 hours urine collection is cumbersome, time consuming and potentially misleading if collected inaccurately. The spot $\mathrm{P} / \mathrm{C}$ ratio has been considered equivalent to 24 -hour urinary protein for predicting proteinuria. Aim of study was to compare spot P/C ratio to 24 hours urinary protein in patients of pre-eclampsia and to determine the fetomaternal outcome in the patients admitted in Dayanand Medical College and Hospital, Ludhiana.

Methods: A prospective simple random study. It included 100 hypertensive pregnant women being evaluated for preelampsia, regardless of the alerting signs or symptoms. The main measures were the urinalysis of patients which included urinary spot $\mathrm{P} / \mathrm{C}$ and 24 hours urinary protein excretion and the fetomaternal outcome in these patients. The data was statistically analyzed.

Results: A good positive correlation existed between the $\mathrm{P} / \mathrm{C}$ ratio and 24 hours protein excretion, with a correlation coefficient (r) of 0.912 . The sensitivity and specificity of 24 hours urinary protein versus spot $\mathrm{P} / \mathrm{C}$ ratio ranged between $86.29 \%-99.51 \%$ and $8.35 \%-99.95 \%$ respectively. The positive and negative likelihood ratio of 24 hours urinary protein versus spot $\mathrm{P} / \mathrm{C}$ ratio was 48 (ranged between 6.89-334) and 0.04 (ranged between 0.01-0.16) respectively. The positive and negative predictive value of 24 hours urinary protein versus spot $\mathrm{P} / \mathrm{C}$ ratio was $97.96 \%$ and $96.08 \%$ respectively. Our data showed that urine spot P/C ratio above $3.9 / \mathrm{mg}$ strongly predicts significant proteinuria of more than 4 gram/day.

Conclusions: Spot urinary P/C ratio with suspected preeclampsia can be used as a rapid alternative test to 24 hours urinary protein.
\end{abstract}

Keywords: Gestational hypertension, Pre-eclampsia, Proteinuria, Spot P/C ratio, Urinalysis, 24 hours urinary protein

\section{INTRODUCTION}

Hypertensive disorder of pregnancy has complicated up to $10 \%$ of pregnancies in the world. It is one of the greatest causes of maternal and perinatal morbidity and mortality worldwide. ${ }^{1}$ Estimated 50,000-60,000 deaths per year worldwide are due to preeclampsia. ${ }^{2,3}$ The incidence of pre-eclampsia in India is $8-10 \%$. In India, it contributes to about $24 \%$ of maternal deaths. ${ }^{4}$ Preeclampsia is a multisystem disorder with widespread endothelial leak. One of the important signs of preeclampsia is proteinuria which occurs as a 
consequence of decreased integrity of glomerular barrier or reduced tubular reabsorption of proteins. It is an important objective criterion for diagnosis of preeclampsia. It has been used to classify the severity of pre-eclampsia as well as to predict adverse fetal and maternal outcomes in preeclampsia.

It remains an important objective criterion for diagnosis of preeclampsia and has been used to classify the severity as well as to predict adverse fetomaternal outcomes in preeclampsia. ${ }^{1}$ Among the various methods available to quantify proteinuria, 24 hours urinary protein estimation remains the gold standard. Alternative methods like a spot urine sample protein-creatinine $(\mathrm{P} / \mathrm{C})$ ratio avoid the influence of variations in urinary solute concentrations and can reduce the delay in diagnosis and management of preeclamptic patients. This study was carried out to assess the diagnostic value of protein: creatinine ratio in single voided urine sample and compared with 24 hours urinary collection for the detection of significant proteinuria in hypertensive pregnant women and the maternal outcome in our study.

\section{METHODS}

This is a prospective study conducted over 100 patients at DMCH, Ludhiana over a period of 1 year, where patients were enrolled for 9 months starting from December 2016 and followed for outcome till December 2017.

\section{Inclusion criteria}

- Study population consisted of booked/un-booked antenatal cases of gestation > 20 weeks with new onset hypertension

- It also included patients with chronic hypertension with new onset of proteinuria and diabetic patients with no proteinuria.

\section{Exclusion criteria}

1. Subjects with concurrent diseases like

- Urinary tract infection

- Renal diseases (known case of chronic kidney disease)

- Autoimmune diseases

- Diabetic nephropathy.

2. Patients who delivered before completion of 24 hours urine sample collection.

It included all women being evaluated for preeclampsia, regardless of the alerting sign or symptom, suspected severity or co- morbid conditions. Informed consent was taken from all participant patients. Urine dipstick was done on for all patients.

- Cases: women presenting with hypertension with or without severe features with urine dipstick showing +1 or more
- Controls: chronological and gestational age matched women with hypertension with urine dipstick showing less than +1 .

The main measures were urinary protein to urinary creatinine ratio by random (spot) direct measurement and the 24 hours urinary protein excretion by a 24 hours urine collection. 24 hours urine collection was started before midday. First morning sample was discarded and the time was noted. Urine was collected in a clean bottle for 24 hours and the last sample will be taken on the next day at the same time.

A single voided urine specimen for spot protein: creatinine ratio was obtained as soon as possible after the 24 hours collection.

All samples were collected via clean catch unless the membranes had been ruptured, in which case specimens will be obtained by catheter. Morning sample will be excluded for estimation of urine $\mathrm{P} / \mathrm{C}$ ratio.

All patients were followed till delivery for maternal and fetal outcome.

The cut off for significant proteinuria for 24 hours urinary protein sample was taken as $300 \mathrm{mg} / 24$ hours.

The cut off for significant proteinuria for spot protein: creatinine ratio was taken as 0.3 .

Total number of patients under study $=100$.

The correlation between the $\mathrm{P} / \mathrm{C}$ ratio in the spot urine samples and urinary protein excretion in the 24 hours collections was examined using the Spearman correlation test.

Sensitivity, specificity, likelihood ratio, positive and negative predictive values were calculated to determine whether spot protein: creatinine ratio could be used as an alternative to 24 hours urinary protein.

\section{Statistical analysis}

The data collected in respect of various variables were analyzed by using different statistical techniques which included T-test, Fischer's exact test, Chi Square test.

\section{RESULTS}

This prospective study was performed in the Department of Obstetrics and Gynecology, Dayanand Medical College and Hospital, Ludhiana to determine whether spot protein: creatinine ratio can be used as an alternative to 24 hours urinary protein in patients of pre-eclampsia and to study the maternal and neonatal outcomes in these patients of hypertensive disorder of pregnancy. 
The mean age of patients with hypertension with proteinuria was 26.23 years and without proteinuria was 26 years. No statistically significant difference was found between the two groups $(\mathrm{p}$ value $=0.065)$. This implies that hypertension without proteinuria (controls) and hypertension with proteinuria (cases) can occur in any age group.

The equal distribution of patients with hypertension according to education level among the two groups ( $p$ value $=0.172)$.

In our study, occupation, gravidity and antenatal care the hypertensive patient received had no effect on distribution of patients between the two groups.

The mean gestational age of patients with hypertension at the time of presentation was $31.03 \pm 3.47$ weeks. Spot protein/creatinine ratio and 24 hours urinary proteins are equivalent in predicting correlation of proteinuria with period of gestation of developing hypertension.

Out of symptoms, headache and blurring of vision show significant relationship with proteinuria.

The mean systolic blood pressure of 100 patients with hypertension was $151.38 \pm 14.76$ and mean diastolic blood pressure was $97 \pm 8.11 \mathrm{mmHg}$. The $\mathrm{p}$ value for determining the mean systolic and diastolic pressure by spot $\mathrm{P} / \mathrm{C}$ ratio was 0.012 and 0.001 and by 24 hours urinary proteins was 0.009 and 0.001 respectively; both of which show a statistically significant relationship between each other.

Out of 100 hypertensive patients in our study, 57 underwent a cesarean section and 43 underwent a vaginal delivery. There were 52 pre-term and 48 term deliveries in our study on 100 patients with hypertension.

The mean period of gestation at the time of delivery in 100 patients with hypertension was $35.14 \pm 3.01$ weeks. Pre-term birth was more common in patients with proteinuria.

In our study, the mean birth weight in 100 patients with proteinuria was $1.82 \pm 0.68 \mathrm{~kg}$ and patients without proteinuria were $2.83 \pm 0.57 \mathrm{~kg}$. Birth weight carries a significant relationship with proteinuria detected by both 24 hours urinary protein and spot $\mathrm{P} / \mathrm{C}$ ratio.

In our study, neither sex of baby nor Apgar score shows a relationship with proteinuria.

In our study, 57 babies born to patients with hypertension got admitted in NICU. Admissions were significantly more in groups with significant proteinuria.

Comparison of accuracy of 24 hours urinary protein with spot protein/creatinine ratio is shown in Table 1 .
Table 1: Comparison of accuracy of 24 hours urinary protein with spot protein/creatinine ratio.

\begin{tabular}{|lll|}
\hline Statistic & Value & $95 \%$ CI \\
\hline Sensitivity & $96.00 \%$ & $86.29 \%$ to $99.51 \%$ \\
\hline Specificity & $98.00 \%$ & $89.35 \%$ to $99.95 \%$ \\
\hline Positive likelihood ratio & 48 & 6.89 to 334.40 \\
\hline Negative likelihood ratio & 0.04 & 0.01 to 0.16 \\
\hline Disease prevalence & $50.00 \%$ & $39.83 \%$ to $60.17 \%$ \\
\hline Positive predictive value & $97.96 \%$ & $87.33 \%$ to $99.70 \%$ \\
\hline Negative predictive value & $96.08 \%$ & $86.30 \%$ to $98.96 \%$ \\
\hline Accuracy & $97.00 \%$ & $91.48 \%$ to $99.38 \%$ \\
\hline
\end{tabular}

Table 2: Comparison of $\mathbf{2 4}$ hours urinary protein with spot protein/creatinine ratio using spearman's rho correlation for accuracy.

\begin{tabular}{|lll|}
\hline $\begin{array}{l}\text { Spearman's } \\
\text { rho }\end{array}$ & \multicolumn{2}{c|}{$\begin{array}{c}\text { Spot protein/cretanine } \\
\text { ratio }\end{array}$} \\
\hline $\begin{array}{l}\text { 24 hours } \\
\text { urinary protein }\end{array}$ & $\begin{array}{l}\text { Correlation } \\
\text { Coefficient }\end{array}$ & 0.912 \\
\hline & p-value & 0.000 \\
\hline & $\mathrm{N}$ & 100 \\
\hline
\end{tabular}

Correlation between spot P:C ratio and 24 hours protein excretion shows a good statistical correlation with correlation coefficient being $0.912(\mathrm{p}=0.000)$.

In our study, the correlation between the spot proteincreatinine ratio and 24 hours protein excretion shows a good positive statistical correlation between the spot protein creatinine ratio and 24 hours protein excretion, with a correlation coefficient $(r)$ being 0.912 . ( $\mathrm{P}$ value 0.000 ) as shown in Table 2.

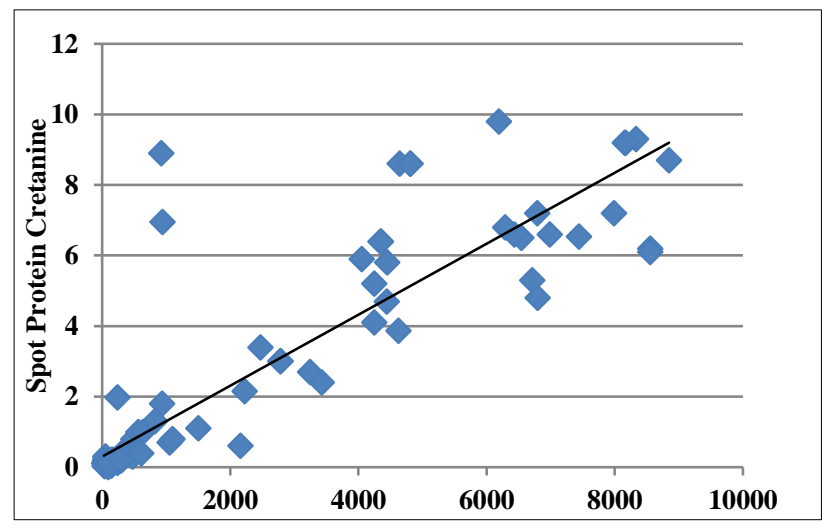

Figure 1: Scatter diagram comparing 24 hours urinary protein and spot protein creatinine ratio by spearman correlation coefficient.

The scatter diagram in Figure 1 shows a linear relationship between the spot protein-creatinine ratio and 24 hours protein excretion.

The ROC curves showing the performance of spot urine $\mathrm{P} / \mathrm{C}$ ratio for different protein ranges in preeclamptic patients. 


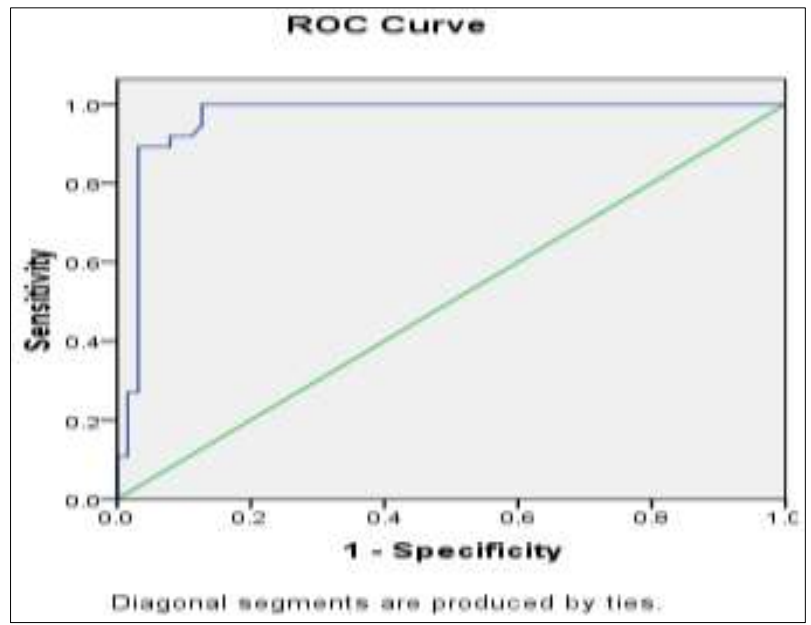

Figure 2: ROC curves showing the performance of spot urine $\mathrm{P} / \mathrm{C}$ ratio for $300 \mathrm{mg}$ proteinuria in preeclamptic patients.

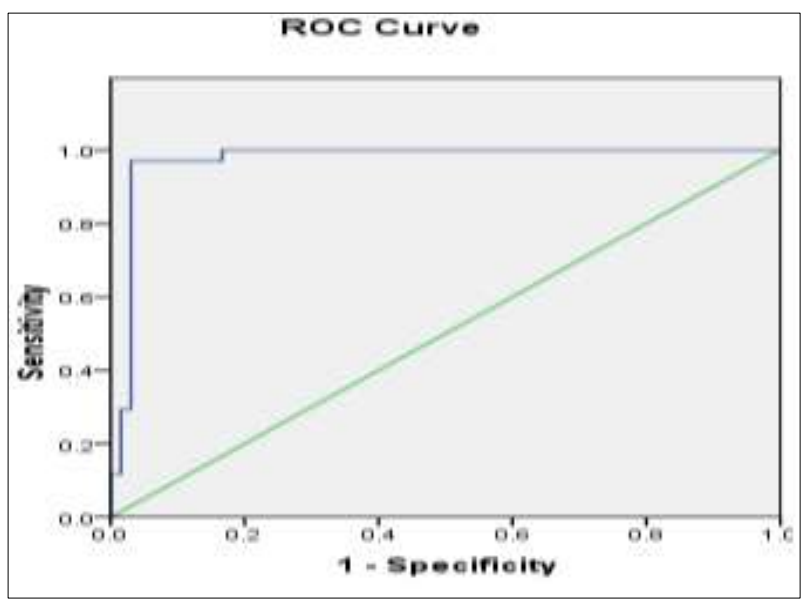

Figure 3: ROC curves showing the performance of spot urine $\mathrm{P} / \mathrm{C}$ ratio for $1000 \mathrm{mg}$ proteinuria in preeclamptic patients.

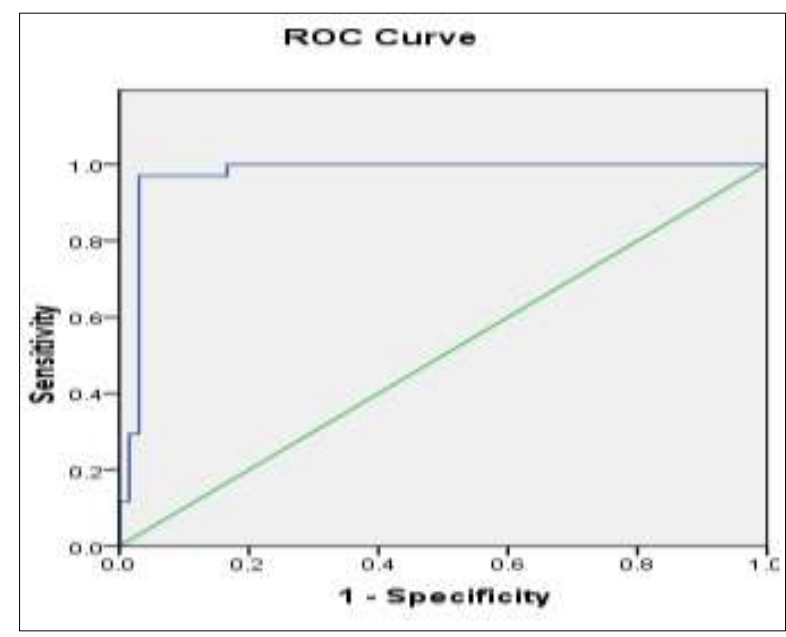

Figure 4: ROC curves showing the performance of spot urine $\mathrm{P} / \mathrm{C}$ ratio for $2000 \mathrm{mg}$ proteinuria in preeclamptic patients.

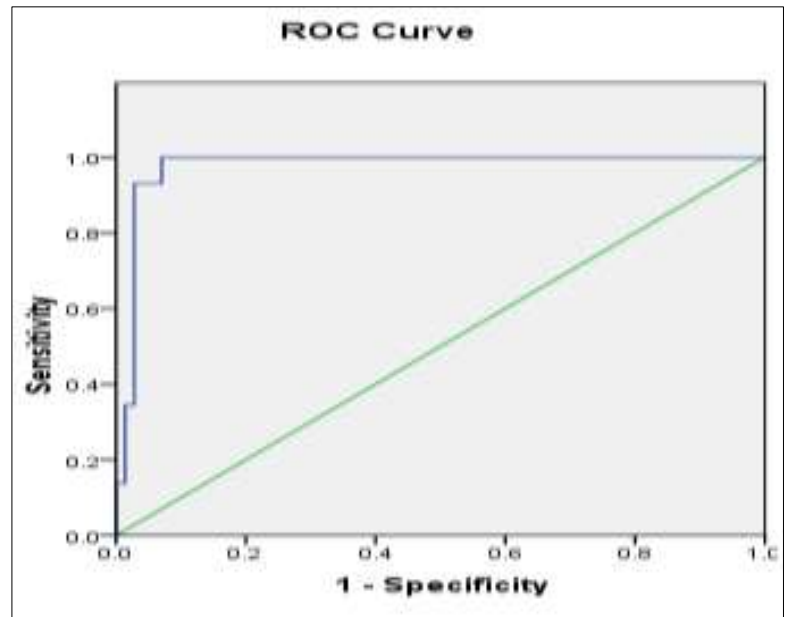

Figure 5: ROC curves showing the performance of spot urine $\mathrm{P} / \mathrm{C}$ ratio for $3000 \mathrm{mg}$ proteinuria in preeclamptic patients.

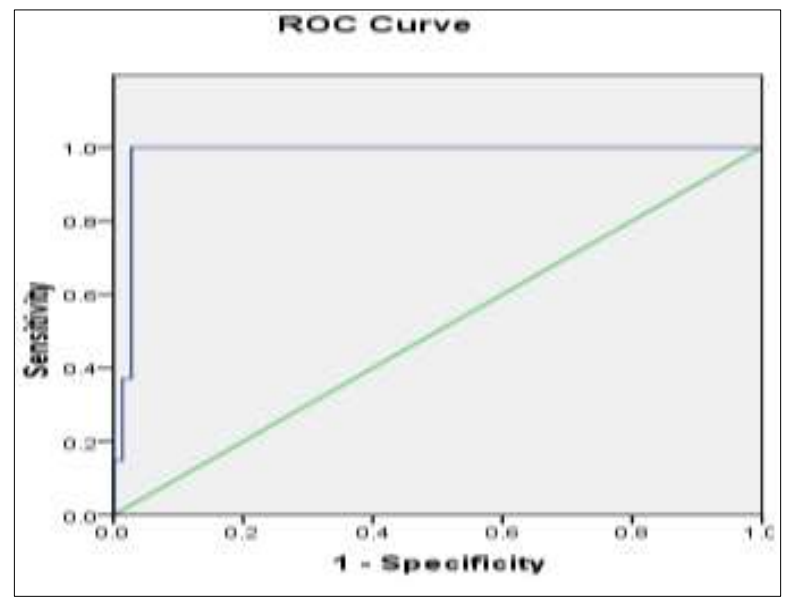

Figure 6: ROC curves showing the performance of spot urine $\mathrm{P} / \mathrm{C}$ ratio for $4000 \mathrm{mg}$ proteinuria in preeclamptic patient.

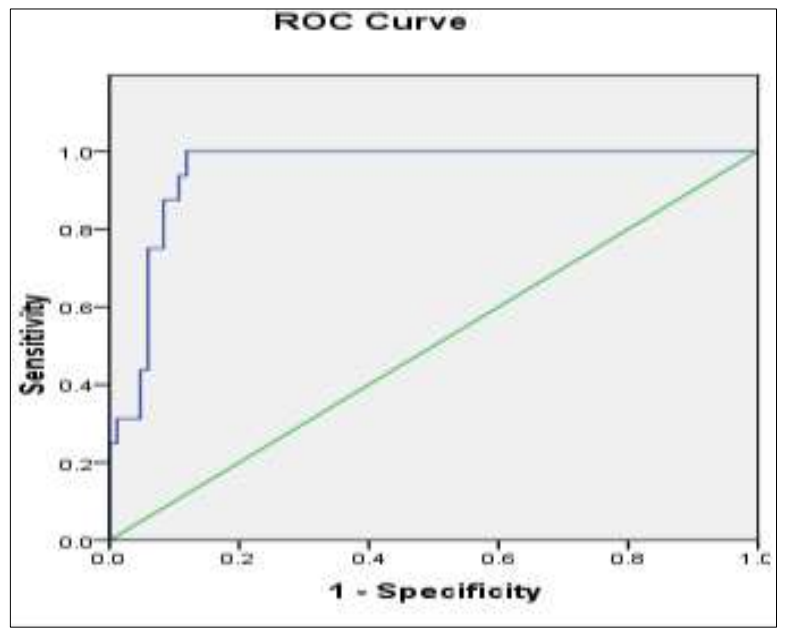

Figure 7: ROC curves showing the performance of spot urine $\mathrm{P} / \mathrm{C}$ ratio for $5000 \mathrm{mg}$ proteinuria in preeclamptic patients. 
By ROC analysis, the best cut-off that gives the maximum area under the curve was 0.35 for $300 \mathrm{mg}$ per 24 hours (AUC: 0.973 , 95\% CI: 0.000-1.000) with $96 \%$ sensitivity and $98 \%$ specificity (Figure 2 ).

A total 0.65 for $1000 \mathrm{mg}$ per 24 hours (AUC: $0.965,95 \%$ CI: $0.925-1.000)$ with $97 \%$ sensitivity and $87 \%$ specificity (Figure 3 ).

A total 2.06 for $1000 \mathrm{mg}$ per 24 hours (AUC: $0.972,95 \%$ CI: $0.000-1.000)$ with $97 \%$ sensitivity and $97 \%$ specificity (Figure 4).

A total 2.55 for $1000 \mathrm{mg}$ per 24 hours (AUC: $0.976,95 \%$ CI: $0.000-1.000)$ with $96 \%$ sensitivity and $93 \%$ specificity (Figure 5).

A total 3.9 for $1000 \mathrm{mg}$ per 24 hours (AUC: $0.980,95 \%$ CI: $0.000-1.000)$ with $96 \%$ sensitivity and $97 \%$ specificity (Figure 6).

A total 5 for $1000 \mathrm{mg}$ per 24 hours (AUC: $0.950,95 \%$ CI: $0.910-0.990)$ with $93 \%$ sensitivity and $88 \%$ specificity (Figure 7).

\section{DISCUSSION}

Preeclampsia is a disorder involving multiple organ system. Renal dysfunction leading to proteinuria (a diagnostic hallmark of preeclampsia), have been used to predict adverse pregnancy outcomes. 24 hours urine protein estimation has been considered the gold standard for testing proteinuria but has the disadvantage of consuming time, delaying diagnosis, and thus delaying initiation of appropriate management. Alternative testing methods like $\mathrm{P} / \mathrm{C}$ ratio on a single random urine sample have correlated well with the gold standard.

This study was conducted to estimate the diagnostic accuracy of spot $\mathrm{P} / \mathrm{C}$ ratio, to evaluate efficacy of 24 hours urinary protein and spot urine $\mathrm{P} / \mathrm{C}$ ratio in predicting the outcomes in preeclampsia.

\section{Demographic parameters}

In our study, the mean age among 100 patients with hypertension in pregnancy was 26.23 years. The extreme ages of reproductive years are well-known risk factors for hypertension during pregnancy. In our study, the mean age of subjects in our study is 26.24 years with mean age in group A and group being 26.48 years (range between 21-37 years) and 26 years (range between 21-41 years) respectively. There was statistically no significant difference between the two groups. The age distribution in both the groups was similar $(\mathrm{p}$ value $=0.065)$. This implies that hypertension with proteinuria and hypertension with proteinuria can occur in any age group. Adeyinka et al. found the prevalence of eclampsia and pre-eclampsia among adolescents to be $20 \%$ in comparison to only $3.33 \%$ among the controls. ${ }^{5}$ Studies have reported that a higher age is also an important risk factor for hypertension in pregnancy, especially in developed countries. Assis et al, found that age above 30 years was associated with a risk for preeclampsia superimposed on chronic hypertension (OR: 5.218; 95\% CI: 1.873 to 14.536$){ }^{6}$

Illiteracy is associated with hypertensive disorder in pregnancy. The illiteracy rate in our population could influence the occurrence of hypertension in pregnancy by the simple reason that the low school level is associated indirectly to the precocious marriage and to limited access to health care, including family planning. But in our study, $56 \%$ of patients with pre-eclampsia were undergraduates, $38 \%$ of patients were graduates and $42 \%$ patients were undergraduates, $40 \%$ graduates in patients with gestational hypertension. The distribution of patients according to education level between the two groups ( $p$ value $=0.172$ ) suggests data, which was not statistically significant. This was supported by study conducted by Ramesh $\mathrm{K}$ et al, for evaluating risk factors for preeclampsia at a tertiary care hospital in Karnataka in the year 2014..$^{7,8}$

\section{Maternal parameters}

In our study, the mean gestational age of patients at the time of presentation was $31.03 \pm 3.47$ weeks. Period of gestation at which patient developed hypertension with significant proteinuria detected by spot protein: creatinine ratio was $29.93 \pm 3.85$ weeks and significant proteinuria detected by 24 hours urinary protein was $29.95 \pm 3.82$ weeks. Patients with significant proteinuria both by 24 hours urinary proteins and spot protein: creatinine ratio developed hypertension at an early gestational age.

In our study, $81.6 \%$ patients with hypertension and proteinuria had headache showing a significant relationship between headache and proteinuria. This is also studied by Facchinetti et al in a study done in Italy in 2005 and concluded the association of pregnancy-induced hypertension with increased vascular reactivity, increased vasoconstrictors, endothelial damage and platelet hyper aggregation causing headache. ${ }^{9}$

Visual symptoms are of a concern in up to $25 \%$ of patients with severe preeclampsia and $50 \%$ of patients with eclampsia. ${ }^{10}$ Preeclampsia/eclampsia has various ocular manifestations. Blurred vision is the most common visual complaint. Retinal vasospasm and resistance to blood flow as a possible explanation for visual symptoms. In our study, $35 \%$ patients with pre-eclampsia had blurring.

The mean systolic blood pressure of 100 patients with hypertension was $151.38 \pm 14.76$ and mean diastolic blood pressure was $97 \pm 8.11 \mathrm{mmHg}$. The $\mathrm{p}$ value for determining the mean systolic pressure by Spot $\mathrm{P} / \mathrm{C}$ ratio is 0.012 and by 24 hours urinary proteins is 0.009 ; both 
of which shows a statistically significant relationship between each other.

The pathophysiology behind hypertensive disorder of pregnancy has been related to abnormal trophoblast invasion of the maternal uterine spiral arteries in early pregnancy, which results in a reduction in the amount of blood flow to the utero-placental bed. ${ }^{11}$ The complexity of this system becomes apparent as similar placental changes are also seen in pregnancies complicated by fetal growth restriction (FGR) without co-existent preeclampsia. These findings are in keeping with the longheld belief that both FGR and pre-eclampsia are likely part of a similar pathophysiological spectrum, being abnormal placental implantation in early pregnancy. Comparison of spot protein: creatinine $(p$ value $=0.055)$ ratio with 24 hours urinary protein shows ( $\mathrm{p}$ value $=$ 0.065) that both of them do not show a correlation between proteinuria and FGR and hence cannot predict the relationship of proteinuria with FGR. Nischintha $\mathrm{S}$ et al conducted a study for correlation between 24 hours urine protein and spot urine protein/creatinine ratio. Fetal complications like FGR increased from 9.8-26.5\% at 24 hours urine protein values of $300 \mathrm{mg}$ or more. Similar findings were reflected in the prediction of adverse fetomaternal outcomes using spot $\mathrm{P} / \mathrm{C}$ ratio, there was no FGR with spot $\mathrm{P} / \mathrm{C}<0.3$, and $19.7 \%$ had fetal complications like with spot urine $\mathrm{P} / \mathrm{C}>0.3 .^{12}$ The $\mathrm{p}$ value 0.005 shows statistical significance, which is not seen in our study.

Optimizing the timing of delivery involves striking a balance between the benefits and risks of pregnancy prolongation compared with those of induction or elective cesarean delivery. Birth of the baby is always in the best interest of the woman. However, we do recognize that women with severe pre-eclampsia remote from term with clinical evidence indicative of fetal compromise (e.g., absent or reversed end-diastolic flow by umbilical artery Doppler) may best be delivered by Caesarean section. Out of 100 hypertensive patients in our study, 57 underwent a cesarean section and 43 underwent a vaginal delivery. This can be explained as majority of patients with proteinuria were delivered at a mean gestation of 33 weeks (far from term). Majority of these were low birth weight with abnormal doppler or oligohydramnios as a complicating factor. Our result was similar in study conducted by Ngwenya $\mathrm{S}$ et al, who researched on accuracy of spot protein/creatinine ratio, stated that most of the patients with pre-eclampsia were delivered by cesarean section $(78.5 \%)$ due to the seriousness of the condition. ${ }^{13}$

\section{Fetal parameters}

Women who developed pre-eclampsia had higher rates of both preterm deliveries at $<37$ weeks of gestation and small-for-gestational-age infants as compared to patients with gestational hypertension (without proteinuria). There were 52 pre-term and 48 term deliveries in our study on
100 patients with hypertension. The mean period of gestation at the time of delivery in 100 patients with hypertension was $35.14 \pm 3.01$ weeks. The mean period of gestation at the time of delivery in patients with proteinuria was $33.18 \pm 3.43$ weeks, which was early as compared to $37.10 \pm 2.59$ weeks in case of patients with hypertension without proteinuria A similar study was conducted by Sami Jan et al in the year 2016 with similar results. ${ }^{14}$

Preeclampsia is a major cause of perinatal morbidity and mortality, and it is very strongly associated with fetal growth retardation leading to low birth weight baby. The process is completely reversed by the delivery of the fetus and placenta, but intrauterine growth retardation and premature delivery pose major threats to the fetus and may require care in a tertiary care center. In our study, the mean birth weight in 100 patients with proteinuria was $1.82 \pm 0.68 \mathrm{~kg}$ and patients without proteinuria was $2.83 \pm 0.57 \mathrm{~kg}$. Distribution of birth weight and its comparison with both spot protein: creatinine ratio and 24 hours urinary protein shows a p value of 0.000 in both the cases, thereby showing a significant relationship between low birth weight and pre-eclampsia.

In our study, distribution of patients according to the Apgar score of baby and its comparison with both spot protein: creatinine ratio and 24 hours urinary protein shows a $p$ value of 0.092 at $1 \mathrm{~min}$ and 0.379 at $5 \mathrm{~min}$ in spot protein: creatinine ratio group and p value of 0.0112 at $1 \mathrm{~min}$ and 0.428 at $5 \mathrm{~min}$ in 24 hours urinary protein group, thereby showing that there is no significant relationship between them. This is in contrast to the study conducted by Kishwara $\mathrm{S}$ et al studied the effects of Preeclampsia by spot protein: creatinine ratio on Perinatal Outcome at a hospital setup in Bangladesh in the year 2016 and found the statistical analysis between the two groups was significant as $\mathrm{p}=0.005$. $^{15}$

\section{Comparison of 24 hours urinary protein and spot protein/creatinine ratio}

A total of 100 women with hypertension were evaluated. 24 hours urinary protein and spot protein/creatinine ratio was sent for all the 100 patients.

The mean 24 hours urinary proteins in 100 patients with hypertension are 2061.9. Significant proteinuria (> 300 $\mathrm{mg}$ /day) on 24 hours urine evaluation were identified in $50 \%(\mathrm{n}=50)$ patients, rest $50 \%$ patients had proteinuria < $300 \mathrm{mg} / 24$ hours. The mean value of 24 hours urinary protein in 50 patients with significant proteinuria (> 300 $\mathrm{mg} / 24$ hours) was $3967.11 \mathrm{mg} / 24$ hours and in $50 \%$ patients with proteinuria $<300 \mathrm{mg} / 24$ hours was 156.69 $\mathrm{mg} /$ day. This signifies that patients with significant proteinuria comprises the preeclampsia group and patients without significant proteinuria comprises the Gestational hypertension group. According to 24 hours urinary protein, out of 100 hypertensive patients, 50 
patients had pre-eclampsia and 50 patients had gestational hypertension (Table 3).

Table 3: Distribution of patients according to 24 hours urinary proteins.

\begin{tabular}{|lll|}
\hline $\begin{array}{l}\text { Value of } 24 \text { hours urinary } \\
\text { proteins }\end{array}$ & $\begin{array}{l}<300 \mathrm{mg} / 24 \\
\text { hours }\end{array}$ & $\begin{array}{l}>300 \mathrm{mg} / 24 \\
\text { hours }\end{array}$ \\
\hline Total number of patients $(\mathrm{n})$ & $\mathrm{N}=50$ & $\mathrm{~N}=50$ \\
\hline $\begin{array}{l}\text { Mean value of } 24 \text { hours } \\
\text { urinary protein }\end{array}$ & 156.69 & 3967.11 \\
\hline
\end{tabular}

Jan $\mathrm{S}$ et al, in a study conducted to determine the Diagnostic accuracy of spot urinary protein/creatinine ratio for proteinuria in pregnancy induced hypertension in 2017 concluded that the mean 24 hours urine proteinuria in patients into preeclampsia was $1.7 \mathrm{~g} /$ day. While as in patients with gestational hypertension, it was $0.2 \mathrm{~g} / \mathrm{day}$. The cut off for 24 hours urinary protein was same as in our study. ${ }^{14}$

The value for significant proteinuria by spot protein: creatinine ratio is taken as $>0.3$. Significant proteinuria (> 0.3) on spot protein: creatinine evaluation were identified in $49 \%(n=49)$ patients, rest $51 \%$ patients had spot protein/creatinine ratio $<0.3$. The mean value of spot protein/creatinine ratio in 49 patients with significant proteinuria (> 0.3 on spot $\mathrm{P} / \mathrm{C}$ ratio) was 4.56 and in in $51 \%$ patients with proteinuria $<0.3$ on spot $\mathrm{P} / \mathrm{C}$ evaluation was 0.19 . The mean spot protein/creatinine ratio in 100 hypertensive pregnant patients was 2.375 . According to spot protein/creatinine ratio, out of 100 hypertensive patients, 49 patients had pre-eclampsia and 51 patients had gestational hypertension. This signifies that patients with significant protein/creatinine ratio comprises the preeclampsia group and patients without significant protein/creatinine ratio comprises the Gestational hypertension group (Table 4).

Table 4: Distribution of patients according to spot protein/creatinine ratio.

\begin{tabular}{|lll|}
\hline $\begin{array}{l}\text { Value of spot protein/ } \\
\text { creatinine ratio }\end{array}$ & $<0.3$ & $>0.3$ \\
\hline Total number of patients $(\mathrm{n})$ & $\mathrm{N}=51$ & $\mathrm{~N}=49$ \\
\hline Mean Spot protein/cretinine ratio & 0.19 & 4.56 \\
\hline
\end{tabular}

In our study, the relationship between the spot proteincreatinine ratio and 24 hours protein excretion shows a good positive statistical correlation between the spot protein creatinine ratio and 24 hours protein excretion, with a correlation coefficient $(r)$ being 0.912 . (P value $0.000)$ This reveals that 24 hours urinary protein and spot protein: creatinine ratio is equivalent in predicting the correlation of proteinuria in pregnancy with hypertension. Montero $\mathrm{N}$ et al showed similar result. ${ }^{16}$

Demirci $\mathrm{O}$ et al in a study conducted in 2015 on spot $\mathrm{P} / \mathrm{C}$ ratio as an alternative to 24 hours urine protein indicated that $\mathrm{P} / \mathrm{C}$ ratio has a good correlation with 24 hours urine protein excretion (r: 0.758). According to their analysis, the optimal $\mathrm{P} / \mathrm{C}$ ratio for detection of urine protein excretion of $300 \mathrm{mg} /$ day was identified as $0.45 \mathrm{mg} / \mathrm{mg}$ with a sensitivity and specificity of $74.4 \%$ and $94.2 \%$, respectively. ${ }^{17}$

Table 5: Performance of spot $\mathrm{P} / \mathrm{C}$ ratio compared to 24 hours urine protein excretion.

\begin{tabular}{|lllll|}
\hline & & & & \\
\hline \\
$300 \mathrm{mg}(\mathrm{n}=50)$ & 0.973 & 0.35 & $96 \%$ & $98 \%$ \\
\hline $2 \mathrm{gm}(\mathrm{n}=37)$ & 0.965 & 0.65 & $97 \%$ & $87 \%$ \\
\hline $3 \mathrm{gm}(\mathrm{n}=29)$ & 0.972 & 2.06 & $97 \%$ & $97 \%$ \\
\hline $4 \mathrm{gm}(\mathrm{n}=27)$ & 0.980 & 2.55 & $96 \%$ & $93 \%$ \\
\hline $5 \mathrm{gm}(\mathrm{n}=16)$ & 0.950 & 3.9 & $96 \%$ & $97 \%$ \\
\hline
\end{tabular}

In our study, the test performance for the spot $\mathrm{P} / \mathrm{C}$ ratio with varying degrees of proteinuria measured by 24 hours urine collection. According to analysis of the ROC curve, the optimal $\mathrm{P} / \mathrm{C}$ ratio for detection of urine protein excretion of $300 \mathrm{mg} /$ day was identified as $0.35 / \mathrm{mg}$ with a sensitivity and specificity of $96 \%$ and $98 \%$, respectively. By ROC analysis, the best cut-off for spot $\mathrm{P} / \mathrm{C}$ ratio that gives the maximum area under the curve for different values of 24 hours urinary protein is given in Table 5 .

However, we found that $\mathrm{P} / \mathrm{C}$ ratio is more sensitive and more specific for the detection of proteinuria $>4 \mathrm{~g} /$ day as area under the curve is maximum in this case. Our data showed that urine spot $\mathrm{P} / \mathrm{C}$ ratio above $3.9 / \mathrm{mg}$ strongly predicts significant proteinuria of more than 4 gram/day. Our cut-off of $4 \mathrm{~g} \mathrm{P} / \mathrm{C}$ ratio can be used in patients with preeclampsia to confirm or exclude abnormal 24 hours losses of protein. Our sensitivity and specificity for the same is $96 \%$ and $97 \%$.

Similar to our study Wheeler et al, reported that $\mathrm{P} / \mathrm{C}$ ratio was $100 \%$ sensitive and specific to detect the proteinuria $>5 \mathrm{~g} /$ day in preeclamptic women. ${ }^{18}$ Random spot $\mathrm{P} / \mathrm{C}$ ratios were strongly correlated with 24 hours urine protein levels (Pearson $\mathrm{r}=0.88$ ). The optimal P/C cutoffs were 0.21 (300 mg per 24 hours) and 3.0 (5000 mg per 24 hours).

\section{CONCLUSION}

It is concluded that, spot urinary $\mathrm{P} / \mathrm{C}$ ratio in hospitalized women with suspected preeclampsia can be used as a screening test as a good predictor for significant proteinuria. Therefore, it could be used as a rapid alternative test in patients with poor clinical status in order to prevent any delay in the implementation of treatment. 


\section{ACKNOWLEDGMENTS}

Authors would like to thank all the residents of obstetrics and gynaecology department of Dayanand Medical College and Hospital, Ludhiana. Authors would also like to thank all the women who participated in this study.

Funding: No funding sources

Conflict of interest: None declared

Ethical approval: The study was approved by the Institutional Ethics Committee

\section{REFERENCES}

1. Report of the National high blood pressure education-program working group on high blood pressure in pregnancy. Am J Obstet Gynecol. 2000;183:S1-S22.

2. Fukui A, Yokota M, Funamizu A, Nakamua R, Fukuhara R, Yamada K, et al. Changes of NK cells in preeclampsia. Am $\mathrm{J}$ Reprod Immunol. 2012;67:278-86.

3. Nelissen EC, van Montfoort AP, Dumoulin JC, Evers JL. Epigenetics and the placenta. Hum Reprod Update. 2011;17:397-417.

4. Pijnenborg R, Vercruysse L, Hanssens M. Fetalmaternal conflict, trophoblast invasion, preeclampsia, and the red queen. Hypertens Preg. 2008;27:183-96.

5. Adeyinka DA, Oladimeji O, Adekanbi TI, Adeyin-ka FE, Falope Y, Aimakhu C. Outcome of adolescent pregnancies in southwestern Nigeria: a case-control study. J Matern Fetal Neonatal Med. 2010;23(8):785-9.

6. Assis TR, Viana FP, Rassi S. Study on the major maternal risk factors in hypertensive syndromes. Arq Bras Cardiol. 2008;91(1):11-7.

7. Ramesh K, Gandhi S, Rao V. Socio-demographic and other risk factors of pre-eclampsia at a tertiary care hospital, Karnataka: case control study. J Clin Diagn Res. 2014;8(9):JC01-JC04.

8. Bdolah Y, Elchalal U, Natanson-Yaron S, Yechiam $\mathrm{H}$, Bdolah-Abram $\mathrm{T}$, Greenfield $\mathrm{C}$, et al. Relationship between nulliparity and preeclampsia may be explained by altered circulating soluble fmslike tyrosine kinase. Hyper Preg. 2014;33(2):250-9.

9. Facchinetti F, Allais G, D'Amico R, Benedetto C, Volpe A. The relationship between headache and preeclampsia: a case-control study. Eur J Obstet Gynecol Reprod Biol. 2005;121(2):143-8.

10. Sunness JS. The pregnant woman's eye. Surv Ophthalmol. 1988;32:219-38.

11. Steinberg G, Khankin EV, Karumanchi SA. Angiogenic factors and preeclampsia. Thromb Res. 2012;123(Suppl 2):S93-99.

12. Nischintha S, Pallavee P, Ghose S. Correlation between 24-h urine protein, spot urine protein/creatinine ratio, and serum uric acid and their association with fetomaternal outcomes in preeclamptic women. J Nat Sci Biol Med. 2014;5(2):255-60.

13. Ngwenya S. Severe preeclampsia and eclampsia: incidence, complications, and perinatal outcomes at a low-resource setting, Mpilo Central Hospital, Bulawayo, Zimbabwe. Int $\mathrm{J}$ Womens Health. 2017;9:353-7.

14. Jan S, Javaid C, Firdous N. Diagnostic accuracy of spot urinary protein/creatinine ratio for proteinurea in pregnancy induced hypertension. Int $\mathrm{J}$ Reprod Contracept Obstet Gynecol. 2017;6(5):2083-9.

15. Kishwara, Tanira S, Omar E, Wazed F, Ara S. Effects of preeclampsia on perinatal outcome- a study done in the specialized urban hospital set up in Bangladesh. Bang Med J. 2016;40(1):33.

16. Montero N, Soler MJ, Pascual MJ, Barrios C, Márquez E, Rodríguez E, et al. Correlation between the protein/creatinine ratio in spot urine and 24-hour urine protein. Nefrol. 2012;32(4):494-501.

17. Demirci O, Kumru P, Arınkan A. Spot protein/creatinine ratio in preeclampsia as an alternative for 24-hour urine protein. Balkan Med J. 2015;32(1):51-5.

18. Martins-Costa SH, Vettorazzi J, Valerio E, Maurmman C, Benevides G, Hemessath M, et al. Protein creatinine ratio in random urine sample of hypertensive pregnant women: Maternal and perinatal outcomes. Hyper Preg. 2011;30:331-7.

Cite this article as: Taneja A, Kaur G, Kaur M, Chaudhary M, Kaur K. pot protein/creatinine ratio as a marker for fetomaternal outcome in hypertensive disorder of pregnancy. Int J Reprod Contracept Obstet Gynecol 2019;8:5014-21. 